\title{
ESTIMATED DURATION OF THE SUBSURFACE REDUCING ENVIRONMENT PRODUCED BY THE Z-AREA SALTSTONE DISPOSAL FACILITY (U)
}

April 25, 2003

PREPARED BY:

Daniel I. Kaplan

Westinghouse Savannah River Company LLC Savannah River Site Aiken, SC 29808

Prepared for the U.S. Department of Energy under Contract No. DE-AC09-96SR18500 
This document was prepared in conjunction with work accomplished under Contract No. DE-AC09-96SR18500 with the U. S. Department of Energy.

\section{DISCLAIMER}

This report was prepared as an account of work sponsored by an agency of the United States Government. Neither the United States Government nor any agency thereof, nor any of their employees, makes any warranty, express or implied, or assumes any legal liability or responsibility for the accuracy, completeness, or usefulness of any information, apparatus, product or process disclosed, or represents that its use would not infringe privately owned rights. Reference herein to any specific commercial product, process or service by trade name, trademark, manufacturer, or otherwise does not necessarily constitute or imply its endorsement, recommendation, or favoring by the United States Government or any agency thereof. The views and opinions of authors expressed herein do not necessarily state or reflect those of the United States Government or any agency thereof.

This report has been reproduced directly from the best available copy.

Available for sale to the public, in paper, from: U.S. Department of Commerce, National Technical Information Service, 5285 Port Royal Road, Springfield, VA 22161, phone: (800) 553-6847, fax: (703) 605-6900

email: orders@ntis.fedworld.gov

online ordering: http://www.ntis.gov/help/index.asp

Available electronically at http://www.osti.gov/bridge

Available for a processing fee to U.S. Department of Energy and its contractors, in paper, from: U.S. Department of Energy, Office of Scientific and Technical Information, P.O. Box 62, Oak Ridge, TN 37831-0062,

phone: (865)576-8401,

fax: (865)576-5728

email: $\underline{\text { reports@ adonis.osti.gov }}$ 
THIS PAGE INTENTIONALLY LEFT BLANK

Rev. 0 
THIS PAGE INTENTIONALLY LEFT BLANK

Rev. 0 


\begin{abstract}
The formula for saltstone includes $\sim 25 \mathrm{wt} \%$ slag to create a reducing environment for mitigating the subsurface transport of a number of radionuclides, including technetium-99. Based on laboratory measurements and mass balance calculations, it was estimated that the Z-Area saltstone waste form will maintain a reducing environment for more than a thousand years and likely for more than 10,000 years. The calculations were very sensitive to infiltration flow rate, underscoring the importance of the proposed moisture barrier for mitigating contaminant transport. Laboratory measurements indicated that the slag used in the formulation of the saltstone has an exceptionally high reduction capacity. Furthermore, measurements of a subsurface SRS sediment indicated that it also had a significant reduction capacity, albeit almost an order of magnitude less than that of the slag. Approximately $78 \%$ of the reduction capacity in the disposal system came from the saltstone, $14 \%$ from the geological materials in the overlying moisture barrier, and $9 \%$ from the vault made from reducing grout.
\end{abstract}




\section{TABLE OF CONTENTS}

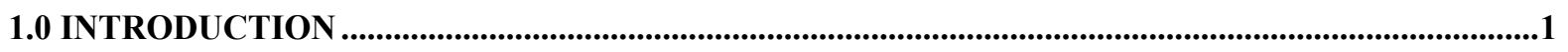

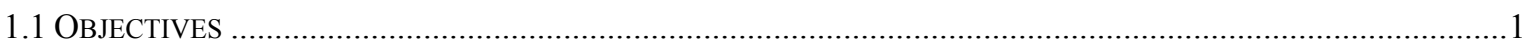

2.0 APPROACH ……................................................................................................................................................

3.0 LABORATORY MEASUREMENTS OF REDUCTION POTENTIAL ...................................................8

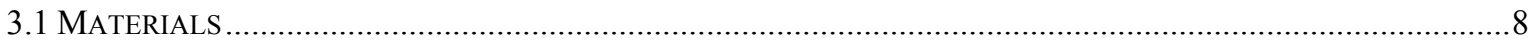

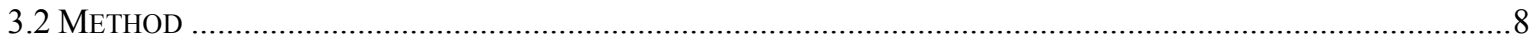

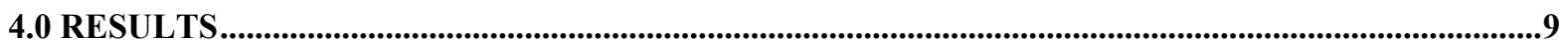

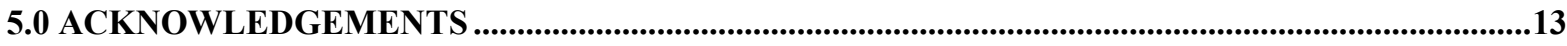

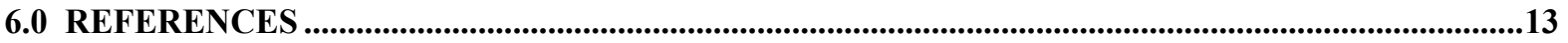

\section{LIST OF FIGURES}

Figure 1. Schematic Representation of the Modeled Saltstone System ............................................5

Figure 2. Reduction Potential and Reduction Capacity of an SRS Subsurface Sediment and the Slag

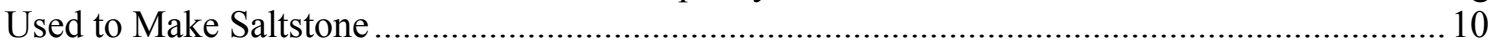

Figure 3. Infiltration Rate Versus Years Until System Becomes Oxidized: (A) Identifies the Infiltration Rates of the Intact Saltstone Vault, Lower Geosynthetic Clay Liner, Upper Geosynthetic Clay Liner, and Intact Sediment; (B) Close up of the Data.................................... 11

Figure 4. Mass Balance of Reduction Capacity in the Saltstone Disposal Facility ............................. 12

\section{LIST OF TABLES}

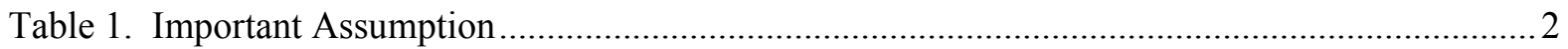

Table 2. Input Values Used to Calculate Duration that Saltstone Maintains a Reducing Subsurface

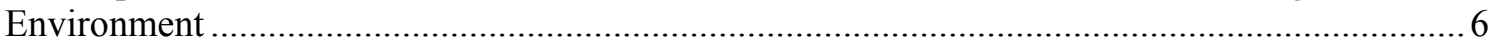

Table 3. Calculations for Estimating Oxidation Capacity of Salt Solution .......................................... 7

Table 4. Sample Descriptions and Weights Used to Measure Reduction Capacity .............................. 9 


\section{LIST OF ACRONYMS AND ABBREVIATIONS}

\section{ACRONYMS}

SRS Savannah River Site

$\begin{array}{ll}\text { ABBREVIATIONS } \\ e^{-} & \begin{array}{l}\text { electron } \\ \eta_{x}\end{array} \\ \rho_{x} & \begin{array}{l}\text { porosity of material } x \\ \text { density of } x\end{array} \\ \mathrm{D}_{x} & \text { Length of } x \\ f_{x} & \text { weight fraction of } x \text { in saltstone } \\ \mathrm{kg} & \text { kilogram } \\ \mathrm{L} & \text { liter } \\ \mathrm{m} & \text { meter } \\ \mathrm{meq} e^{-} \mathrm{L}^{-1} & \text { milli electron equivalents } \\ \mathrm{mL} & \text { milliliter } \\ \mathrm{mV} & \text { millivolts } \\ O_{x} & \text { electron equivalents of oxidizing agent } x \\ R_{\mathrm{x}} & \text { electron equivalents of reducing agent } x \\ t & \text { time } \\ \mathrm{yr} & \text { year }\end{array}$




\subsection{INTRODUCTION}

The nominal blend composition of saltstone is $3 \mathrm{wt} \%$ lime source, $25 \mathrm{wt} \%$ fly ash, $25 \%$ slag, and $47 \mathrm{wt} \%$ salt solution (Heckrotte 1988). The addition of slag to the saltstone formulation provides a chemical reductant [iron(II)] and a precipitating agent [sulfide] that chemically binds several contaminants as insoluble species, thus reducing the tendency of these contaminants to leach from the solid waste form. Experimentation has shown that leaching of chromium and technetium was effectively reduced to a level that enabled all projected salt solution compositions to be processed into a non-hazardous solid waste (MMES 1992). Long-term lysimeter studies have shown that the addition of slag into the saltstone formulation essentially stopped technetium-99 leaching, but did not reduce nitrate leaching (MMES 1992).

\subsection{Objectives}

The objective of this study was to estimate how long reducing conditions would exist in the saltstone subsurface environment. Ambient conditions in the Z-Area subsurface are oxidizing, due to the omnipresence of oxygen in air. It is expect that eventually, the reducing capacity of the slag will be exhausted by a number of naturally occurring processes, the most important being the consumption of oxidation of the slag by dissolved oxygen $\left(\mathrm{O}_{2}\right)$ in infiltrating rainwater.

\subsection{APPROACH}

An electron-equivalent mass balance was conducted to calculate the duration that the Z-Area Saltstone Disposal Facility would remain reducing (Figure 1). Electron equivalents are the units used to describe the concentration (more precisely, the activity) of free electrons that can participate in an oxidiation-reduction, or redox, reaction. The generalized redox equation is presented in Eq 2.0-1.

$$
O+e^{-}=R
$$

where

$$
\begin{array}{lll}
O & = & \text { oxidizing agent, meq } \mathrm{e}^{-} \mathrm{L}^{-1}, \\
R & = & \text { reducing agent, meq } \mathrm{e}^{-} \mathrm{L}^{-1}, \text { and } \\
e^{-} & = & \text {electron. }
\end{array}
$$

The greatest concentration of reductant will exist in the disposal facility when it is initially placed in the ground and then over time, the concentration of reductant will slowly decrease as more dissolved oxygen in groundwater consumes the saltstone reductant. Once the reduction capacity is exhausted, the saltstone will no longer be able to bind the targeted radionuclides, such as technetium-99, in the less mobile reduced form. It is important to note, that theoretically the redox potential, i.e., the intensity term to describe the redox status in a system, will remain at a low fixed value until the last mole of reductant in the slag is consumed, at which point the redox potential will make a step-wise increase to a value controlled by the next dominant redox couple, which is likely iron(II/III). Once all the iron(II) has been oxidized to iron (III) then manganese(IV/II) will likely control the redox status in the system. This step-wise increase in redox potential will continue until the system is in equilibrium with the surrounding soil/water/air system.

For these calculations, it was assumed that the reducing capacity of the saltstone equaled that provided by the slag and the overlying geological material in the moisture barrier. The oxidizing capacity was set equal to the amount of dissolved oxygen introduced into the system by infiltrating rainwater and the salt solution used to create the saltstone. Once the cumulative amount of oxidizing agent equaled that of the slag and overlying moisture barrier, the capacity of the saltstone to 
chemically (as opposed to physically) immobilize reducible radionuclides was assumed to be exhausted. The mass balance equation describing these reactions is presented in Eq. 2.0-2.

$$
O_{\text {infiltrating groundwater }}+O_{\text {salt solution }}=R_{\text {soil }}+R_{\text {slag }}
$$

where

$$
\begin{array}{lll}
O_{\text {infiltrating groundwater }}= & \begin{array}{l}
\text { electron equivalents of oxidizing agent from infiltrating } \\
\text { groundwater, meq } e^{-} \mathrm{m}^{-2},
\end{array} \\
O_{\text {salt solution }} & = & \begin{array}{l}
\text { electron equivalents of oxidizing agent from salt solution, meq } e^{-} \mathrm{m}^{-2}, \\
R_{\text {soil }}
\end{array} \\
R_{\text {slag }} & = & \text { electron equivalents of reducing agent from soil, meq } e^{-} \mathrm{m}^{-2}, \text { and }
\end{array}
$$

The important assumption made for these calculations are presented in Table 1.

\section{Table 1. Important Assumption}

1 The system is well mixed, such that all saltstone reductants at $100 \%$ efficiency are available for oxidation by infiltrating water. $100 \%$ efficiency of oxygen reducing the slag will not happen; some of the oxygen will not react or will be channeled past reducing areas. This is perhaps the most conservative assumption; however, it is necessary because there is no data quantifying the efficiency of this reaction.

2 Formulation of saltstone and especially the concentration of slag remains the same for all saltstone waste forms.

3 No formation of hardened coatings on saltstone to impede oxidation of slag by oxygenated infiltrating water. These will form, thus this is a conservative assumption.

4 Reduction capacity of native soil equals that of moisture barrier. Since the design of the barrier has not bee finalized, it is not clear whether this assumption is conservative. As the moisture barrier ages, its reduction capacity will approach that of the native soil. The 2:1 clays commonly used in geosynthetic clay lines have higher reduction capacities than SRS soils.

5 Chromium(VI/III) redox couple used in the reduction capacity measurement is similar to that of groundwater oxygen( $0 /-\mathrm{II})$. Chromium standard reduction potential is slightly more negative, hence the measurement underestimates the reduction capacity of the saltstone and native soil. 
he electron equivalents of oxidizing agent from infiltrating rainwater was assumed to be equal to that provided by dissolved oxygen. Dissolved oxygen concentrations were set equal to $2.65 \mathrm{E}-4 \mathrm{M}$, a value calculated using Henry's Law and one that is quite similar to those commonly measured in SRS surface sediment porewater (Kaplan and Serkiz 2000) (Table 2). The amount of oxygenated groundwater that came into contact with the saltstone was estimated using infiltration rate and porosity (Eq. 2.0-3).

$$
O_{\text {infiltraing groundwater }}=C_{\text {infiltrating groundwater }} \times 1000 \times i_{\text {saltstone }}+\eta_{\text {saltstone }}+t
$$

where

$\begin{array}{lll}O_{\text {infiltraing groundwater }} & = & \begin{array}{l}\text { electron equivalents of oxidizing agent from infiltrating } \\ \text { groundwater, meq } e^{-} \mathrm{m}^{-2},\end{array} \\ C_{\text {infiltrating groundwater }} & = & \text { oxidient concentration in groundwater, meq } e^{-} \mathrm{L}^{-1}, \\ 1000 & = & \text { conversion factor, } \mathrm{L} \mathrm{m}^{-3}, \\ i_{\text {saltstone }} & = & \text { saltstone infiltration rate, } \mathrm{m} \mathrm{yr}^{-1}, \\ \eta_{\text {saltstone }} & = & \text { saltstone porosity, } \mathrm{m}^{3} \mathrm{~m}^{-3}, \text { and } \\ t & = & \text { time, } \mathrm{yr} .\end{array}$

The electron equivalents of oxidizing agent in the salt solution were based on the concentration of constituents that are likely reduced by the slag in the nominal blend of ITP and ETF feed solutions at 8:1 mixing (Heckrotte 1988). Molybdenum and chromate in the salt solution were considered reducible. Nitrate and sulfate in the salt solution were not considered reducible because nitrates have been shown to leach from saltstone lysimeters and sulfate is not reduced in grout (MMES 1992). There were several trace constituents, including several radionuclides (e.g., cobalt, iodine, plutonium, and technetium) that were not included in these calculations because their concentrations are extremely low. Their sum contribution to the saltstone electron equivalents is $<0.001 \mathrm{wt} \%$. The details for calculating the total concentration of oxidizing agents is presented in Table 3 and the mass balance equation is presented in Eq. 2.0-4.

$$
O_{\text {salt solution }}=C_{\text {salt solution }} \times 1000 \times 1 / \rho_{\text {salt solution }} \times f_{\text {salt solution }} \times \rho_{\text {saltstone }} \times D_{\text {salstone }}
$$

where

$\begin{array}{lll}O_{\text {salt solution }} & = & \begin{array}{l}\text { electron equivalents of oxidizing agent from salt solution, } \\ \text { meq } e^{-} \mathrm{m}^{-2},\end{array} \\ C_{\text {salt solution }} & = & \text { oxidizing constituents concentration in salt solution, meq } e^{-} \mathrm{L}^{-1}, \\ 1000 & = & \text { conversion factor, } \mathrm{L} \mathrm{m}^{-3}, \\ f_{\text {salt solution }} & = & \text { weight fraction of salt solution in saltstone, } \mathrm{kg} \mathrm{kg}^{-1}, \\ \rho_{\text {salt solution }} & = & \text { density of salt solution, } \mathrm{kg} \mathrm{m}^{-3}, \\ \rho_{\text {saltstone }} & = & \text { density of saltstone, } \mathrm{kg} \mathrm{m}^{-3}, \text { and } \\ D_{\text {saltstone }} & = & \text { saltstone height, } \mathrm{m} .\end{array}$


The reduction capacity of the geological materials above the vaults, $R_{\text {soil }}$, was calculated using Eq. 2.0-5. $R_{\text {soil }}$ was calculated using a value, $C_{\text {soil }}$, measured from a McBean/Barnwell formation sediment, the same geologic formation as the Z-Area Saltstone Disposal Facility. Being a measured value, as oppose to a calculated value, provides added credibility to it. At this writing, the design for the moisture barrier has not been finalized, but it will likely contain a number of different layered materials. The use of only the one native sediment to approximate these various materials provides a reasonable long term average, and not necessarily a conservative value. More details about this measurement are provided in the next section, Section 3.0 Laboratory Measurements of Reduction Potential.

$$
R_{\text {soil }}=C_{\text {soil }} \times \rho_{\text {soil }} \times D_{\text {soil }}
$$

where

$$
\begin{array}{lll}
R_{\text {soil }} & = & \begin{array}{l}
\text { reduction capacity of soil, meq } e^{-} \mathrm{m}^{-2} . \\
C_{\text {soil }}
\end{array} \\
\rho_{\text {soil }} & = & \text { reduction capacity of soil, meq } e^{-} \mathrm{kg}^{-1}, \\
D_{\text {soil }} & = & \text { density of soil, } \mathrm{kg} \mathrm{m}^{-3}, \text { and } \\
& \text { soil height, } \mathrm{m} .
\end{array}
$$

The value used in these calculations for the reduction capacity of the slag, $R_{\text {slag }}$, was based on a laboratory measurement (described in more detail in the next section, Section 3.0 Laboratory Measurements of Reduction Potential).

$$
R_{\text {slag }}=C_{\text {slag }} \times \rho_{\text {saltstone }} \times f_{\text {slag }} \times D_{\text {saltstone }}
$$

where

$\begin{array}{lll}R_{\text {slag }} & = & \text { reduction capacity of slag, meq } e^{-} \mathrm{m}^{-2} . \\ C_{\text {slag }} & = & \text { reduction capacity of slag, meq } e^{-} \mathrm{kg}^{-1}, \\ \rho_{\text {saltstone }} & = & \text { density of saltstone, } \mathrm{kg} \mathrm{m}^{-3}, \\ f_{\text {slag }} & = & \text { weight fraction of slag in saltstone, } \mathrm{kg} \mathrm{kg}^{-1} \text {, and } \\ D_{\text {saltstone }} & = & \text { saltstone height, } \mathrm{m} .\end{array}$




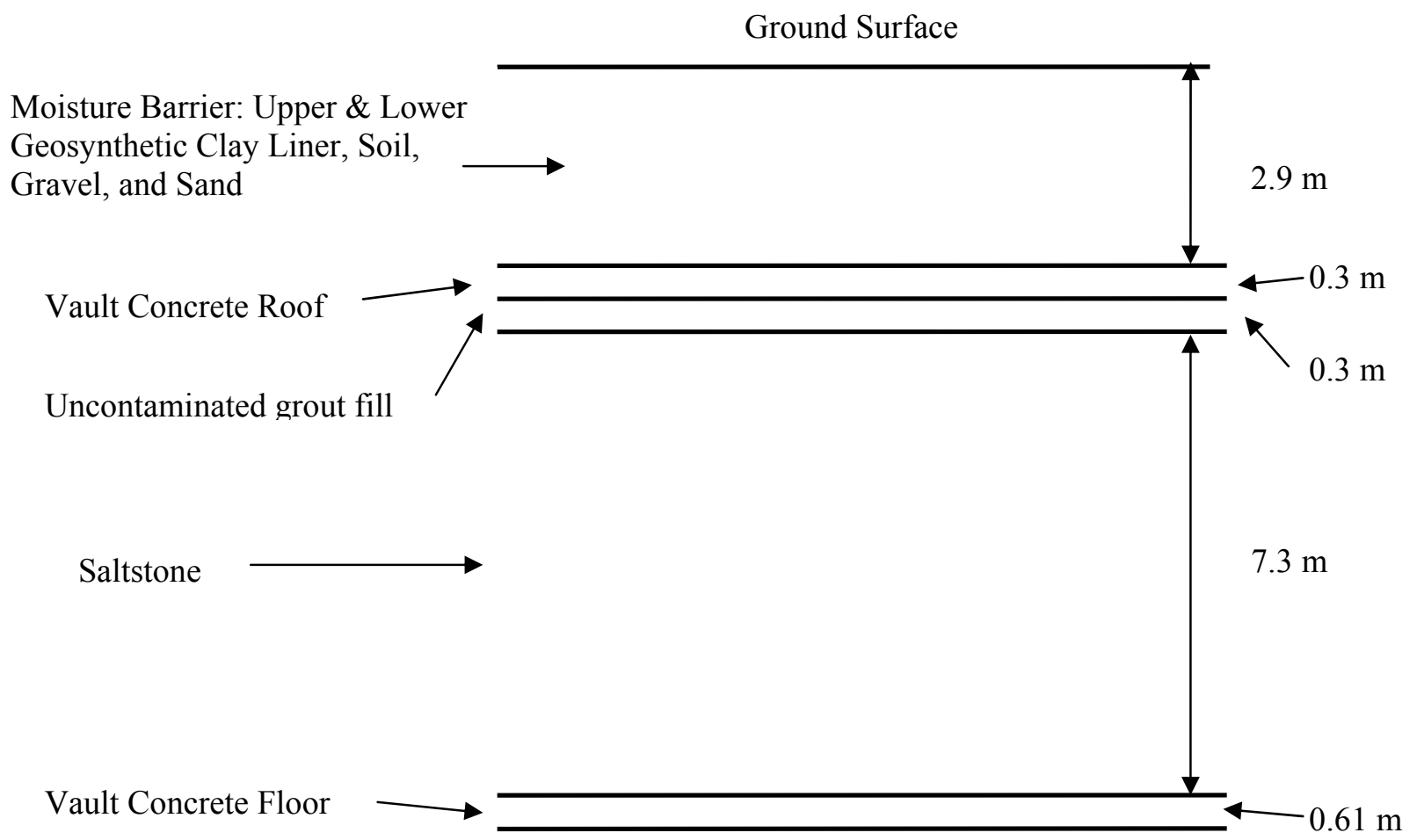

Figure 1. Schematic Representation of the Modeled Saltstone System 
Table 2. Input Values Used to Calculate Duration that Saltstone Maintains a Reducing Subsurface Environment

\begin{tabular}{|c|c|c|c|}
\hline & Parameter (symbol; units) & Value & Comments/Source \\
\hline \multirow{6}{*}{ Grout } & Grout height, vault and saltstone made with reducing grout & & \\
\hline & $\left(D_{\text {saltstone }} ; \mathrm{m}\right)$ & 8.51 & WSRC-RP-92-1360; p. 2-62, 2-72 \\
\hline & Grout height, saltstone made with reducing grout $\left(D_{\text {salstone }} ; \mathrm{m}\right)$ & 7.6 & WSRC-RP-92-1360; p. 2-62, 2-72 \\
\hline & Saltstone bulk density $\left(\rho_{\text {saltstone }} ; \mathrm{kg} \cdot \mathrm{m}^{-3}\right)$ & $1.70 \mathrm{E}+03$ & WSRC-RP-92-1360; p. 2-56 \\
\hline & Fraction of slag in saltstone $\left(f_{\text {slag }} ; \mathrm{kg}\right.$ slag $\left.\cdot[\mathrm{kg} \text { saltstone }]^{-1}\right)$ & 0.25 & WSRC-RP-92-1360; p. 2-56 \\
\hline & Reduction capacity of slag $\left(C_{\text {slag }} ;\right.$ meq $\left.\mathrm{e}^{-} \cdot[\mathrm{kg} \mathrm{slag}]^{-1}\right)$ & 37 & Measured, see Figure 2; "Reduction Capacity v1.xls" \\
\hline \multirow[t]{10}{*}{ Water } & Infiltration rate - grout/saltstone $\left(i_{\text {salstone } ;} \mathrm{m} \cdot \mathrm{yr}^{-1}\right)$ & 40 & Dependent variable; WSRC-RP-92-1360; p. 2-72 \\
\hline & Infiltration rate $-\operatorname{soil}\left(i_{\text {soil } ;} \mathrm{m} \cdot \mathrm{yr}^{-1}\right)$ & 40 & Dependent variable; Estimate WSRC-RP-92-1360; p. 2-72 \\
\hline & Porosity - vault/saltstone $\left(\eta_{\text {saltstone }} ;\right.$ vol water $\left.\cdot[\text { vol saltstone }]^{-1}\right)$ & 0.46 & email "saltstone" 21April03, Jim Cook (WSRC) \\
\hline & Porosity - soil $\left(\eta_{\text {soil }} \mathrm{m}^{3}\right.$ water $\left.\cdot\left[\mathrm{m}^{3} \text { total }\right]^{-1}\right)$ & 0.46 & Conservative average of several materials \\
\hline & Volume of infiltrating water/yr - vault-saltstone $/ \mathrm{yr}\left(\mathrm{L} \cdot\left[\mathrm{yr}-\mathrm{m}^{2}\right]^{-1}\right)$ & 184 & Calculated from infiltration rate and porosity \\
\hline & Volume of infiltrating water $/ \mathrm{yr}-$ soil $\left(\mathrm{L} \cdot\left[\mathrm{yr}-\mathrm{m}^{2}\right]^{-1}\right)$ & 184 & Calculated from infiltration rate and porosity \\
\hline & Henry's Law Constant for $\mathrm{O}_{2}\left(\mathrm{~mol} \cdot \mathrm{atm}^{-1}\right)$ & $1.26 \mathrm{E}-03$ & Stumm and Morgan (1996); p. 214 \\
\hline & $\mathrm{O}_{2}$ concentration in air $(\mathrm{atm})$ & 2.10E-01 & CRC Handbook; 65th Ed. \\
\hline & $\mathrm{O}_{2}$ concentration in groundwater $(\mathrm{M})$ & $2.65 \mathrm{E}-04$ & Near identical to measured values ${ }^{a}$ \\
\hline & $\mathrm{O}_{2}$ electron equiv. in groundwater $\left(C_{\text {infiltrating groundwater }} ;\right.$ meq e- $\left.\cdot \mathrm{L}^{-1}\right)$ & $1.06 \mathrm{E}+00$ & 4 electrons per $\mathrm{O}_{2}$ molecule ${ }^{\mathrm{a}}$ \\
\hline \multirow[t]{4}{*}{ Soil } & Soil Cover Depth $\left(D_{\text {soil }} ; \mathrm{m}\right)$ & $2.92 \mathrm{E}+00$ & WSRC-RP-92-1360; p. 2-71 \\
\hline & Soil Reduction Capacity $\left(C_{\text {soil }}\right.$, meq e- $\left.\cdot[\mathrm{kg} \text { soill }]^{-1}\right)$ & $5.10 \mathrm{E}+00$ & Measured, see Figure 2; "Reduction Capacity v1.xls" \\
\hline & Soil Density $\left(\rho_{\text {soil }}, \mathrm{kg} \cdot \mathrm{m}^{-3}\right)$ & $1.50 \mathrm{E}+03$ & Dragun $1998 ;$ p. 10 \\
\hline & Soil Reduction Capacity $\left(C_{\text {soil }}\right.$, meq e- $\left.\cdot\left[\mathrm{m}^{3} \text { soil }\right]^{-1}\right)$ & $7.65 \mathrm{E}+03$ & \\
\hline
\end{tabular}

\footnotetext{
${ }^{\mathrm{a}}$ Used to calculate $C_{\text {infiltrating groundwater }}$;
} 


\section{Table 3. Calculations for Estimating Oxidation Capacity of Salt Solution}

\begin{tabular}{|c|c|c|c|c|}
\hline $\begin{array}{l}\text { Oxidizing } \\
\text { Ingredient }\end{array}$ & $\begin{array}{l}\text { Saltstone } \\
\text { Feed }^{(a)} \\
\left(\text { moles L }^{-1}\right)\end{array}$ & $\begin{array}{l}\text { e- equivalents } \\
\text { required to } \\
\text { reduce } 1 \text { mole } \\
\left(\text { meq e- } \mathrm{mol}^{-1}\right)\end{array}$ & $\begin{array}{l}\mathrm{e}^{-} \text {equivalents } \\
\text { consumed by } \\
\text { saltstone } \\
\left(\mathrm{meq} \mathrm{e}-\mathrm{L}^{-1}\right)\end{array}$ & Comments \\
\hline nitrates & $>2.00 \mathrm{E}+00$ & & & Nitrate leaches from lysimeters, thus not reduced by slag \\
\hline $\mathrm{Na}_{2} \mathrm{CrO}_{4}$ & $3.06 \mathrm{E}-03$ & 3000 & $9.18 \mathrm{E}+00$ & $\mathrm{Cr}(\mathrm{VI})$ not leached from lysimeters, likely reduced by slag; $\mathrm{Cr}(\mathrm{VI})$ to $\mathrm{Cr}(\mathrm{III})$ \\
\hline $\mathrm{Na}_{2} \mathrm{MoO}_{4}$ & $3.61 \mathrm{E}-04$ & 2000 & $7.22 \mathrm{E}-01$ & $\mathrm{Mo}(\mathrm{VI})$ to $\mathrm{Mo}(\mathrm{IV})$ \\
\hline $\mathrm{Na}_{2} \mathrm{SO}_{4}$ & $1.22 \mathrm{E}-01$ & & & Not reduced by slag \\
\hline $\mathrm{CaSO}_{4}$ & $3.06 \mathrm{E}-03$ & & & Not reduced by slag \\
\hline Total $^{(\mathrm{b})}$ & & & $9.90 \mathrm{E}+00$ & \\
\hline
\end{tabular}

(a) Nominal Blend from ITP \& ETF (Table 2.3-3 in WSRC-RP-92-1360; page 2-41)

${ }^{\text {(b) }}$ Skipped any salt solution ingredients that had a concentrations $>1 \mathrm{e}-4$ molar. 


\subsection{LABORATORY MEASUREMENTS OF REDUCTION POTENTIAL}

The objective of the laboratory work was to measure the reduction capacity of the slag used to make saltstone and of a sediment collected from the Barnwell/McBean formation, the geological formation where the Z-Area Saltstone Disposal Facility is located. Following is a detailed description of the procedure adapted from Lee and Batchelor (2003).

\subsection{Materials}

1. Z-100 Slag: Provided by Chris Langton, who in turn got it directly from Saltstone Silos.

2. Glovebag

3. $1000-\mathrm{mL}_{10 \mathrm{mM} \mathrm{NaHCO}}$ : Add $0.84 \mathrm{~g} \mathrm{NaHCO}_{3}$ (F.W. $\left.=84\right)$ to a 1-L volumetric flask and then bring it up to volume with water.

4. $100-\mathrm{mL} 51.5 \mathrm{mM} \mathrm{Cr}(\mathrm{VI})$ in $10 \mathrm{mM} \mathrm{NaHCO}_{3}$ : Place $1.000 \mathrm{~g}$ of $\mathrm{K}_{2} \mathrm{CrO}_{4}$ (F.W. $\left.=194.2\right)$ in a $100-\mathrm{mL}$ volumetric flask and then bring up to volume with $10 \mathrm{mM} \mathrm{NaHCO}_{3}$.

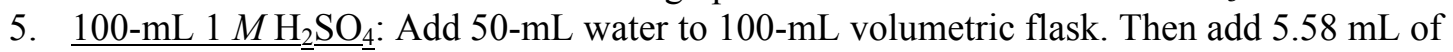
concentrated $\mathrm{H}_{2} \mathrm{SO}_{4}$ to water. Bring to volume with water.

6. $100-\mathrm{mL} 1 \mathrm{M} \mathrm{NaOH}$ : Add 4-g NaOH $(\mathrm{FW}=40)$ to a $100-\mathrm{mL}$ volumetric flask and bring up to volume with water.

7. $\mathrm{Na}_{2} \mathrm{SO}_{4}$ : Pre-weigh 6 aliquots into weighing boats containing $0.142 \mathrm{~g}$ of $\mathrm{Na}_{2} \mathrm{SO}_{4}$

8. $950-\mathrm{mL}$ centrifuge tubes

9. Minilysimeter sediment, a sandy loam soil described in Hawkins (1982).

\subsection{Method}

1. Label 9 tared 50-mL centrifuge tubes as described in Table 4.

2. Add $1.00 \mathrm{~g}$ slag to Tubes \#21, \#22, and \#23. Add $1.00 \mathrm{~g}$ Minilysimeter sediment to Tubes $\# 27$, \#28, and \#29. Only liquid will go into the 3 controls, Tubes \#24, \#25, and \#26. Record weight to Table 4.

3. Place tubes, solutions \#3, \#4, \#5, and \#6, six 0.142-g $\mathrm{Na}_{2} \mathrm{SO}_{4}$ aliquots, and litmas paper into glovebag for 2 days before proceeding to next step. After one day in the glovebag stir things up to help $\mathrm{O}_{2}$ gas diffuse out of solids and liquids.

4. Add $10 \mathrm{~mL}$ of the $51.5-\mathrm{mM} \mathrm{Cr}(\mathrm{VI})$ in $10-\mathrm{mM} \mathrm{NaHCO}_{3}$ solution to each tube.

5. Adjust the $\mathrm{pH}$ of each tube to $7 \pm 1$ by adding $\mathrm{NaOH}$ or $\mathrm{H}_{2} \mathrm{SO}_{4}$.

6. Shake by hand every $\sim 3$ hours for 1 day.

7. Add 0.142-g Na $\mathrm{SO}_{4}$ aliquots to each tube.

8. Shake and leave in bag for $>0.5$ days.

9. Pull tubes out of glovebag, record weight of "tube + solid + liquid" on Table 4, centrifuge, and pass through a $0.45-\mu \mathrm{m}$ filter.

10. Send to ADS for $\mathrm{Cr}$ analysis by ICP-ES. 
Table 4. Sample Descriptions and Weights Used to Measure Reduction Capacity (Example)

\begin{tabular}{|c|c|c|c|c|}
\hline ID & Description & $\begin{array}{l}\text { Tube Tare Wt } \\
(\mathrm{g})\end{array}$ & $\begin{array}{c}\text { Tube }+ \\
\text { Solid wt (g) }\end{array}$ & $\begin{array}{l}\text { Tube }+ \text { solid } \\
+ \text { liquid }(g)\end{array}$ \\
\hline 21 & Slag, Rep. 1 & & & \\
\hline 22 & Slag, Rep. 2 & & & \\
\hline 23 & Slag, Rep. 3 & & & \\
\hline 24 & Control (just liquid), Rep. 1 & & & \\
\hline 25 & Control (just liquid), Rep. 2 & & & \\
\hline 26 & Control (just liquid), Rep. 3 & & & \\
\hline 27 & Sediment, Rep. 1 & & & \\
\hline 28 & Sediment, Rep. 2 & & & \\
\hline 29 & Sediment, Rep. 3 & & & \\
\hline
\end{tabular}

\subsection{RESULTS}

Laboratory measurements of the reducing capacity of an SRS sediment and slag are presented in Figure 2. These values indicate that the slag has a very high reducing capacity. Furthermore, it shows that our soils also have a measurable reducing capacity. This reducing capacity is likely the result of naturally occurring iron(II) phases in the sediment. By way of comparison, Lee and Batchelor (2003) reported that a Texas loam and pyrite (FeS) had a reducing capacity of 6.1 and 32 meq $\mathrm{kg}^{-1}$, respectively. These values are certainly in line with the values reported in Figure 2. Also shown in Figure 2 are the reduction potential (Eh) values of 1:1 solid:water suspensions. Reduction potential is an intensity term, i.e., it does not express the total concentration of reducing agents in a system, instead it provides an estimate of the concentration of reducing agents in solution in equilibrium with a solid. Alternatively and less accurately, it can be thought of as a measurement of the free electron activity, as defined in (Eq. 2.0-1). The soil and slag had reduction potentials of $196 \pm$ 3 and $-247 \pm 1 \mathrm{mV}$, respectively. Reducing systems have lower, more negative, reduction potentials. By way of comparison, Kaplan et al. (2003) reported that metallic iron $\left(\mathrm{Fe}^{0}\right)$ had a reduction capacity of $-173 \pm 6 \mathrm{mV}$. This value is consistent with the slag reduction potential value reported in Figure Figure 2.

At this writing, the infiltration rates to be used for the various layers at the disposal site (Figure 1) have not been finalized. So to calculate the reducing lifespan of the saltstone system, infiltration rate was used as a dependent variable (Figure 3). Figure 3 shows that the reducing lifespan, if limited by the infiltration rate of the intact saltstone vault (2.54E-07 m yr ${ }^{-1}$; Phifer 2003), would be 1.29 billion years. Obviously, this infiltration rate will not last for such a long duration because the saltstone vaults will have physically degraded. At the other extreme, the reducing lifespan, if limited by the infiltration rate of intact sediment $\left(0.4 \mathrm{~m} \mathrm{yr}^{-1}\right.$; MMES 1992), would be 800 years. This latter scenario is akin to assuming that water will flow through the moisture barrier and vaults at the same rate as water flows through native sediment. A more likely and still reasonably conservative estimate is to assume that the upper geosynthetic clay liner will eventually degrade and then water will flow through the vault at a rate limited by the lower geosynthetic clay liner, $0.0016 \mathrm{~m}$ $\mathrm{yr}^{-1}$ (Phifer 2003). At this rate, the reducing lifespan of the vault system would be 180,000 years. 
Regardless of the infiltration rate, the reducing capacity of the saltstone will account for $77 \%$ of the total reducing capacity, whereas the overlying moisture barrier (assumed to have the reducing capacity of native sediment) will account for $14 \%$, and the vault, made from reducing grout, will account for $9 \%$ of the total reducing capacity (Figure 4). Thus, relatively little reducing capacity is gained by including slag in the vault cement. The data presented in Figure 3 assumed that the system contained a reducing grout vault. To assume that the vault was not made with reducing grout, all the values shown in Figure 3 would be reduced by $9 \%$. Native sediment offers a relatively large amount of reduction capacity. But it is important to distinguish between capacity, in units of meq $\mathrm{e}^{-} \mathrm{L}^{-1}$ and intensity, in units of $\mathrm{mV}$. SRS soil has been shown to reduce oxygen $\left(\mathrm{O}_{2}\right.$; Kaplan and Serkiz 2000) and chromate $\left(\mathrm{CrO}_{4}{ }^{2-}\right.$; Kaplan and Serkiz 2000), but not pertechnetate $\left(\mathrm{TcO}_{4}{ }^{-}\right.$; Kaplan 2003) or iodide (I'; Kaplan 2003). So although SRS soils have a measurable reduction capacity, the resulting reduction potential is not sufficiently low to reduce pertechnetate or iodide. Therefore, it would be incorrect to assume that the reducing capacity of the soil beneath the vaults would offer additional protection against pertechnetate or iodide migration.
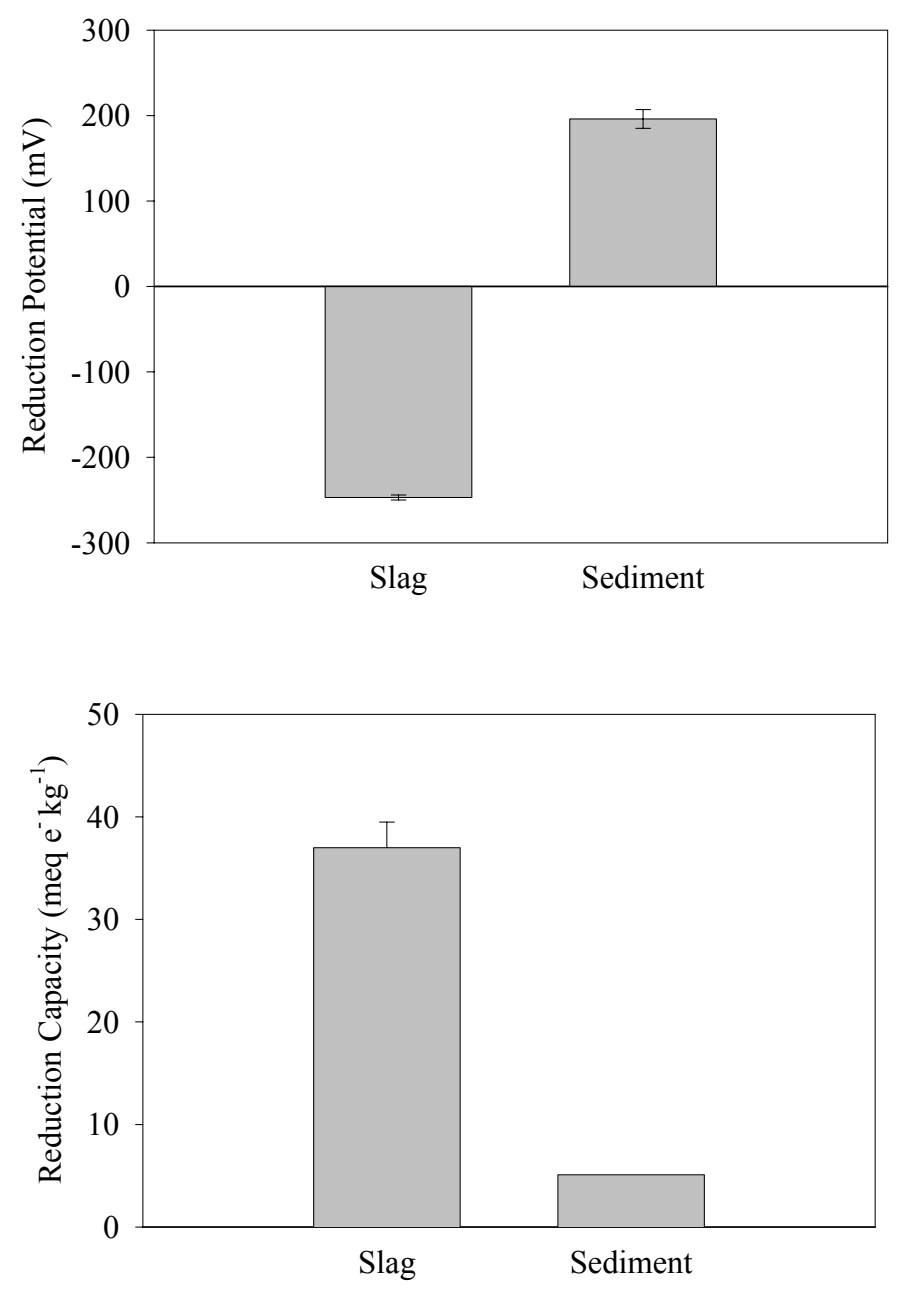

Figure 2. Reduction Potential and Reduction Capacity of an SRS Subsurface Sediment and the Slag Used to Make Saltstone 


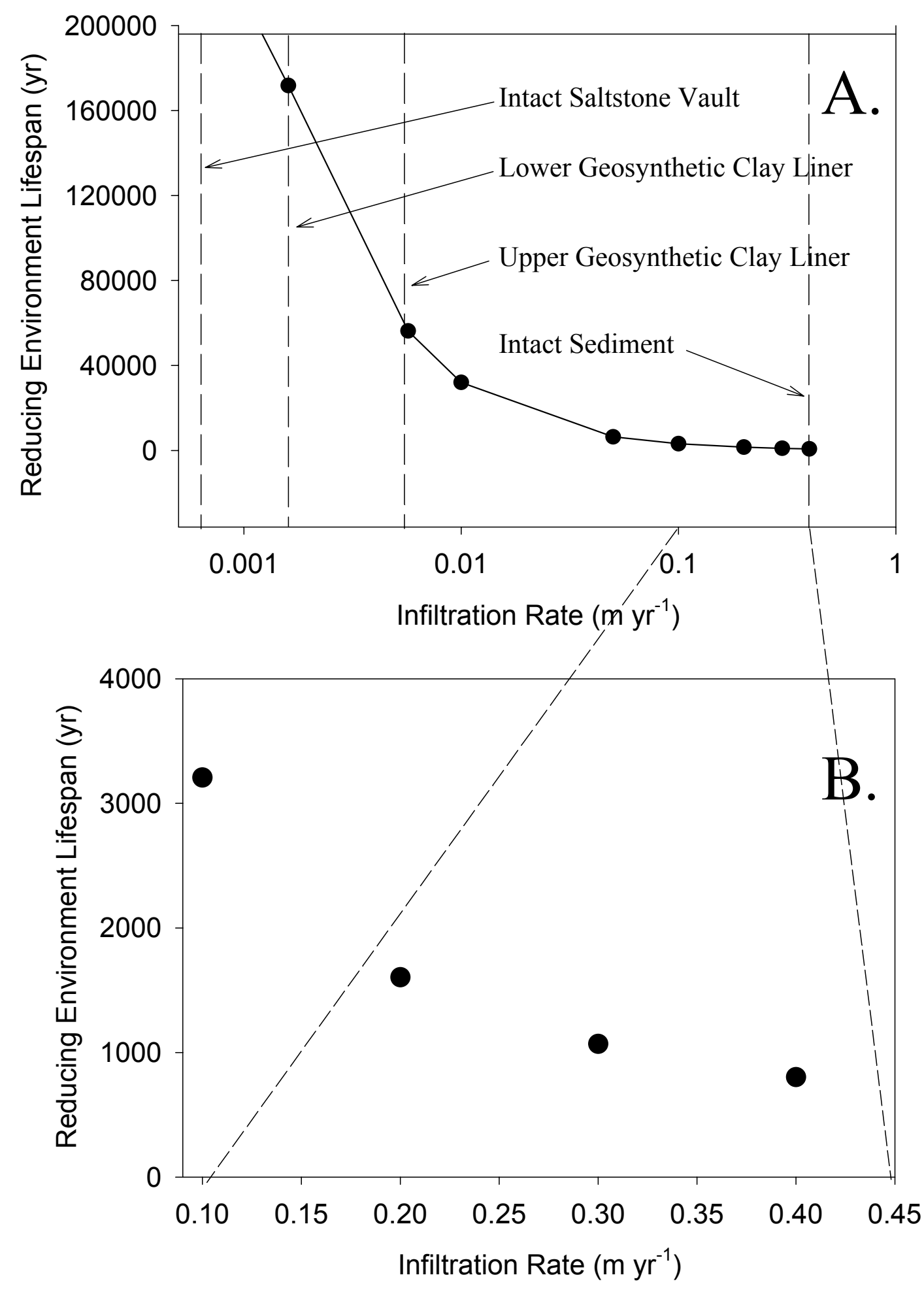

Figure 3. Infiltration Rate Versus Years Until System Becomes Oxidized: (A) Identifies the Infiltration Rates of the Intact Saltstone Vault, Lower Geosynthetic Clay Liner, Upper Geosynthetic Clay Liner, and Intact Sediment; (B) Close up of the Data. 
Page 12

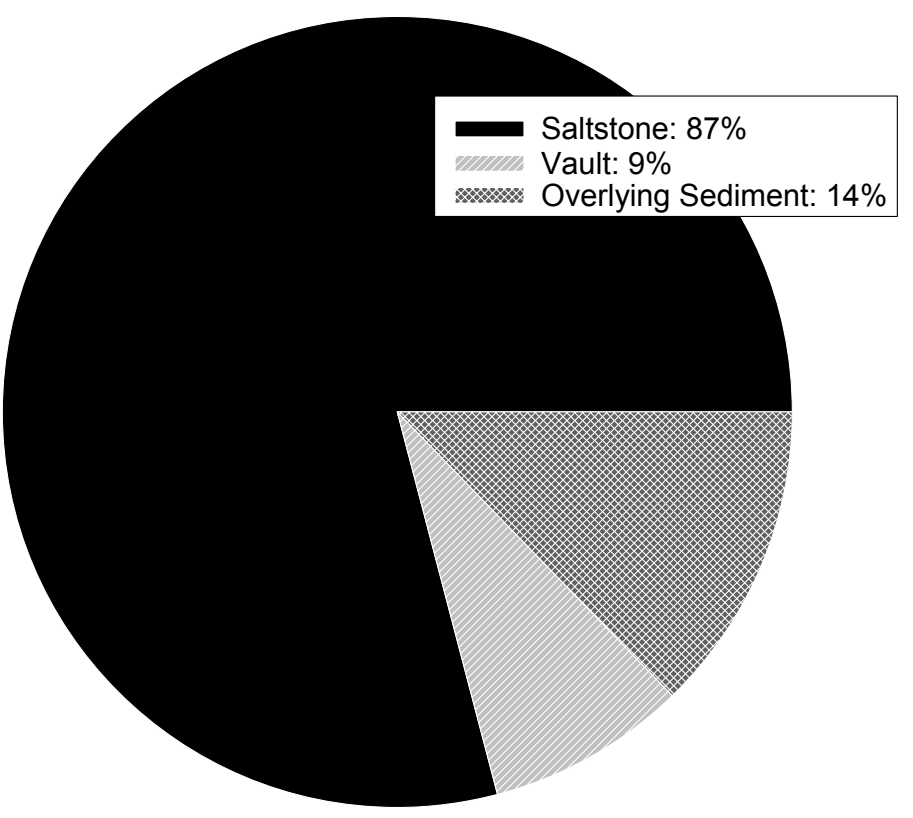

Figure 4. Mass Balance of Reduction Capacity in the Saltstone Disposal Facility 


\subsection{ACKNOWLEDGEMENTS}

The laboratory work was conducted by Cathy Coffey (WSRC). Steve Serkiz conducted a time consuming in depth review of the assumptions and calculations.

\subsection{REFERENCES}

Dragun, J. 1998. The Soil Chemistry of Hazardous Materials, 2nd edition, Amherst Scientific Publishers, Amherst, Massachusetts.

Heckrotte, R. W. 1988. Project S-1780 - Savannah River Plant - 200-S Area Defense Waste Processing Facility - Sludge Plant Request to Modify the DWPF Saltstone Industrial Solid Waste Permit, Inter-office Memorandum, PP-001183, DuPont, Savannah River Plant, Aiken South Carolina.

Kaplan, D. I. 2003. Influence of Surface Charge of an Fe-oxide and an Organic Matter Dominated Soil on Iodide and Pertechnetate Sorption, Radiochim. Acta 91, 173-178.

Kaplan, D. I., A. S. Knox, and C. Coffey. 2002. Reduction of Contaminant Mobility at the TNX Outfall Delta Through the use of Apatite and Zero-valent Iron as Soil Amendments. WSRC-TR-200200370, Rev. 0. Westinghouse Savannah River Company, Aiken, South Carolina.

Kaplan, D. I., and S. M. Serkiz. 2000. In-situ Kd Values and Geochemical Behavior for Inorganic and Organic Constituents of Concern at the TNX Outfall Delta, WSRC-TR-99-00488, Westinghouse Savannah River Company, Aiken, South Carolina.

Lee, W., and B. Batchelor 2003. Reductive Capacity of Natural Reductants, Environmental Science Technology 37, 535-541.

MMES (Martin Marietta Energy Systems, Inc., EG\&G Idaho, Inc., Westinghouse Hanford Company, and Westinghouse Savannah River Company). 1992. Radiological Performance Assessment for the Z-Area Saltstone Disposal Facility, WSRC-RP-92-1360, Westinghouse Savannah River Company, Aiken, South Carolina.

Phifer, M. A. 2003. Saltstone Disposal Facility (SDF) Closure Cap Configuration Drainage Configurations and HELP Model Interface with Vadose Zone Modeling DRAFT, Westinghouse Savannah River Company, Aiken, South Carolina.

Stumm, W., and J. J. Morgan 1996. Aquatic Chemistry, Chemical Equilibria and Rates in Natural Waters, 3rd edition, John Wiley and Sons, Inc., New York, New York. 